\title{
Physicochemical characteristic of modified edible film made from gelatine of sea bass (Lates calcarifer) residue with palmitic acid and soybean protein isolate treatment
}

\author{
${ }^{1}$ Agustini, T.A., ${ }^{1}$ Nurohman, W., ${ }^{1}$ Raharjo, D.P.K., ${ }^{1}$ Wijayanti, I., ${ }^{1}$ Romadhon, D.,

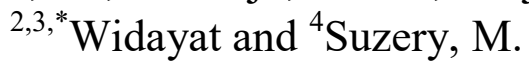 \\ ${ }^{I}$ Fish Product Technology Department, Faculty of Fisheries and Marine Science, Diponegoro University Jl. \\ Prof Soedarto SH Tembalang, Semarang 50275 \\ ${ }^{2}$ Chemical Engineering Department, Faculty of Engineering, Diponegoro University Jl. Prof Soedarto SH \\ Tembalang, Semarang 50275 \\ ${ }^{3}$ Halal Research Center Central Laboratory for Research and Service Unit DIponegoro University Jl. Prof \\ Soedarto SH Tembalang, Semarang 50275 \\ ${ }^{4}$ Department of Chemistry Faculty of Science and Mathematics Diponegoro University Jl. Prof Soedarto SH \\ Tembalang, Semarang 50275
}

\begin{abstract}
Article history:
Received: 3 November 2020

Received in revised form: 18 December 2020

Accepted: 22 February 2021

Available Online: 26

September 2021
\end{abstract}

\section{Keywords:}

Gelatin,

Edible film,

Halal,

Lates calcalifer

DOI:

https://doi.org/10.26656/fr.2017.5(5).626

\begin{abstract}
The use of fish waste as raw material in producing gelatin becomes important when it is related to the halal perspective. Sea bass skin contains high protein, especially collagen protein which can be used as the main component of edible film. An edible film made from gelatin of fish skin usually lacks water vapour transmission due to its hydrophilic properties. Modification of formula in producing an edible film from fish gelatin with the addition of lipid such palmitic acid (PA treatment) and soybean protein isolate (SPI treatment) can affect the characteristics of the edible film resulted. This study was aimed to evaluate the chemical (solubility, water vapour permeability) and physical characteristics (thickness, tensile strength, per cent elongation, SEM) of an edible film made from gelatin with the addition of palmitic acid and soybean protein isolate with different concentration. The results showed that edible films with SPI addition yield the best film thickness $(<2.5 \mathrm{~mm})$ while PA addition resulted in better tensile strength of the films (>3.92 MPa) according to the Japanese Industrial Standard. The per cent elongation of both films with PA (21.3-34.44\%) and SPI (36.06-117.53\%) addition decreased with increasing concentration, but SPI generally gave higher elongation compared to PA. The addition of SPI gave lower solubility and higher water vapour transmission values compared to PA, however, the addition of $4.5 \%$ of PA gave the lowest water vapour transmission $\left(5.416 \mathrm{~g} / \mathrm{m}^{2} \mathrm{~h}\right)$. Therefore, the best treatment in this study was concluded to be $4 \%$ of SPI addition based on the best thickness, per cent elongation, water vapour transmission and solubility results.
\end{abstract}

\section{Introduction}

Fish skin contains high protein, particularly collagen which can be used as the main component for an edible film (Arumugam et al., 2018; Govindharaj et al., 2019). Apart from fish skin, gelatine can also be made from fishbone which contained collagen. Gelatine can be utilized as a thickening agent, stabilizer in the food industry and also a potential raw material for the edible film. This tasteless, colourless, solid substance was generated from the hydrolysis of collagen. Collagen is the most abundant protein component of skin, tendons, connective tissue, cartilage, and bones and it is a major type of macromolecule constituent of the animal body (Lv et al., 2019).

Gelatine is known for its film-forming capacity giving transparent films, which make it an excellent edible film component that can fulfil commercial packaging needs (Hosseini and Gómez-Guillén, 2018). Films that can be consumed directly were widely known as edible films, which lately has been used as a food coating and/or packaging. These films can maintain food quality by retaining the transfer of water vapour, gas, odour, and lipid (Bourtoom, 2008), hence also improving the appearance of the product. Gelatine matrix allows 
controlling of bioactive substances released from the packaging film to the coated food during the storage period and thereby slowing down the deterioration of food products. Bioactive peptides from collagen and gelatine with biological properties have become a topic of great interest for healthy food and processing/ preservation industries (Abdelhedi et al., 2019). However, edible films made from fish gelatine has a concern of subpar protection from water due to its hydrophilic tendency, so its usage is still restricted for low water content product.

Previous studies showed that films containing fatty acids presented higher water vapour barrier properties (Fakhouri et al., 2018). Palmitic acid is a long-chain fatty acid with good film-forming characteristics (Pangesti et al., 2014) which can be added in edible film production to improve the hydrophobic properties of the film (Pereira et al., 2019) and hence decreasing the water vapour transfer. Apart from palmitic acid, soybean protein isolate was also known to improve the characteristics of edible film. Soybean protein isolate (SPI) is a mixture of proteins with different molecular properties which is the abundant, inexpensive, biodegradable, and nutritional raw material (Galus, 2018). It can protect food products from water vapour and gas, reduce oxygen permeability and improve the functional and mechanical properties of the film (Bai et al., 2012; Alves et al., 2017).

The rising demand for gelatine has led to the research for alternatives to mammalian-derived gelatine, particularly in response to health concerns (mammalianderived gelatine were believed to be able to transmit pathogenic vectors such as prions) or religious aspects (forbidden to consume of any pork or beef-related products) (Huang et al., 2019; Nilsuwan et al., 2019). One of the potential alternatives was the use of fish waste or residue which referred to parts that have low or no commercial value such as skin, bones, fins, head and guts (Caruso, 2016). Fishing industries generated close to 32 million tonnes of fish waste every year from fish processing, creating a high concern in its waste management and environmental effects such as accumulation of waste sludge and fish parts in near-shore locations, bad odour and unhygienic conditions caused by bacteria and waste decomposition (Joseph et al., 2019). The utilization of the waste was limited to fish meal and production of organic fertilizer (Tugiyono et al., 2020; Muttharasi et al., 2019; Radziemska et al., 2019), with the rest disposed back to the ocean. Therefore, using fish waste as the raw material for gelatine production was probable since it is readily available, inexpensive and rich in collagen.
The objectives of this study were (i) to develop an edible film made from sea bass (Lates calcalifer) skinderived gelatine and (ii) to investigate the effect of different palmitic acid and soybean isolate protein concentrations on the physicochemical characteristics of the edible film.

\section{Materials and methods}

\subsection{Materials}

Materials used in this study include sea bass skin residues obtained from local markets in Semarang, Indonesia, palmitic acid (98\%, Merck, Germany), soybean protein isolate (Merck, Germany), acetic acid (96\%, Merck, Germany), glycerol (85\%, Merck, Germany) and demineralized water. Equipment used includes an analytical scale (PR124, OHAUS, China), hot plate magnetic stirrer (MS7-H550-S, DLAB, China), and oven (DZF-6020, MTI Corporation, USA). Micrometre screw gauge (125-103, Mitutoyo, Japan) was used to determine film thickness, Synchro-lectric viscometer (RVT, Brookfield, USA) was used to determine the viscosity, film texture was analyzed using TA-XT plus Texture Analyser (Stable Micro System, UK), tensile strength and per cent elongation were determined using Universal Testing Machine (BLGRS500N, ZwickRoell, US) and film surface morphology was characterized using Scanning Electron Microscope (JSM 6510 LA, JEOL, Japan).

\subsection{Methods}

This study was done in two steps, the first step was gelatine production using a modified method studied by Trilaksani et al. (2012). First, degreasing of the fish skin was carried out by washing and submerging the skins in hot water $\left(70^{\circ} \mathrm{C}\right)$ for $1 \mathrm{~min}$. Next, the degreased skins were demineralized by soaking it in $3 \%$ acetic acid for $12 \mathrm{hrs}$ with fish to acid weight ratio of $1: 4$. It was followed by washing with demineralized water until the skin has a $\mathrm{pH}$ of 5-6. Collagen extraction was carried out with fish to demineralized water ratio of $1: 3$ at $70^{\circ} \mathrm{C}$ for $2 \mathrm{hrs}$. The extract was filtered and poured into a clean tray and dried at $60^{\circ} \mathrm{C}$ using the oven for $48 \mathrm{hrs}$ to obtain the gelatine. Laboratory analysis for gelatine covers: yield, gel strength and viscosity.

The second step was edible film production using the modified method of Julianto et al. (2011), where $5 \mathrm{~g}$ of gelatine was dissolved in $100 \mathrm{~mL}$ demineralized water and heated at $85^{\circ} \mathrm{C}$ using the hot plate magnetic stirrer. Glycerol $(0.75 \mathrm{~mL})$ was added into the mixture and various concentrations of palmitic acid $(0 \%, 1.5 \%, 3 \%$ and $4.5 \%$ ) was also mixed into the mixture. The mixture was heated at $55^{\circ} \mathrm{C}$ and stirred for 30 mins. The edible 
film mixture was poured into a glass plate covered with plastic and dried at $60^{\circ} \mathrm{C}$ for $24 \mathrm{hrs}$ before cooled in room temperature. These steps were repeated with soybean protein isolate $(3 \%, 4 \%$ and $5 \%)$ addition instead of palmitic acid. The edible film was analysed for per cent elongation, solubility, thickness, tensile strength, water vapour transmission, and surface morphology. The study used Completely Randomised design with triplicate for each treatment.

\subsection{Water vapour transmission}

The water vapour transmission test was carried out based on ASTM (1993) by placing the sample to cover the permeable cell tube with $4 \mathrm{~cm}$ in diameter. Inside the permeable cell, silica gel was added into the $(0 \% \mathrm{RH})$. Then the cell was covered with film and placed in a desiccator which has been filled with saturated $\mathrm{NaCl}$ $(70 \% \mathrm{RH})$ at a temperature of $30^{\circ} \mathrm{C}$. Water vapour transmission rate was calculated by weighing the permeable cell with 1-hour interval monitoring by using screw gauge micrometre.

$$
\text { WVTR }=\frac{\text { Slope }}{\text { Sample area }\left(\mathrm{m}^{2}\right)}=\mathrm{kgf} / \mathrm{cm}^{2}
$$

\subsection{Per cent elongation}

The per cent elongation was determined based on tensile strength following ASTM (1993). Per cent elongation was calculated using a formula as follow:

$$
\text { Elongation }(\%)=\frac{\text { Final film length }- \text { initial film length }}{\text { initial film length }} \times 100 \%
$$

\subsection{Thickness}

The thickness of the edible film was measured by using screw gauge micrometre $(0.001 \mathrm{~mm}$ precision $)$ with 5 different locations on four sides and centre of the edible film $(2 \times 5 \mathrm{~cm})$ as shown in Figure 1. Thickness was calculated for the average of five measurements.

$$
\text { Thickness }(\mathrm{mm})=\frac{A+B+C+D+E}{5}
$$

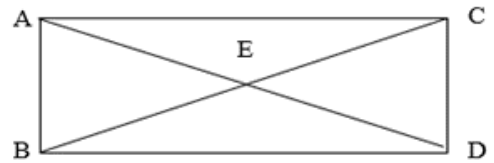

Figure 1. Diagram of thickness calculation

\subsection{Tensile strength}

Tensile strength was determined by using texture analyzer TA-TX. Edible film of $5 \times 2 \mathrm{~cm}$ was measured for its thickness by screw gauge micrometre, then it was placed on the grip. Tensile strength was calculated by formula as follows (Wibowo et al., 2016):

$$
\Sigma=\frac{N}{T \times L}=M p a
$$

\subsection{Yield}

The yield of the gelatine was determined from the gelatine obtained and the raw material used based on AOAC (2005). The following equation was used to calculate:

$$
\text { Yield }(\%)=\frac{\text { Dry gelatine weight }(g)}{\text { Wet fish skin weight }(g)} \times 100 \%
$$

\subsection{Viscosity}

Gelatine mixture (6.67\%) was prepared by dissolving gelatine produced in demineralized water. The viscosity of the gelatine was measured using Synchrolectric viscometer at $60^{\circ} \mathrm{C}$ with stirring speed of $60 \mathrm{rpm}$ and 1 spindle. Viscosity value was measured in centipoise (cP) unit (British Standard 757, 1975).

\subsection{Gel Strength}

Gelatine mixture $(6.67 \%)$ was prepared by dissolving gelatine in demineralized water at $80^{\circ} \mathrm{C}$ for 15 mins. The mixture was poured into Standard Bloom Jars (d: $58-60 \mathrm{~mm}$, h: $85 \mathrm{~mm}$ ), left for 2 mins to settle before put into the Texture Analyzer TA-XT machine. The gel strength was measured at $0.5 \mathrm{~mm} / \mathrm{s}$ probe speed with 4 $\mathrm{mm}$ depth. The gel strength value was measured in bloom unit (British Standard 757, 1975).

\section{Results and discussion}

\subsection{The characteristics of gelatine made from sea bass} skin

Parameter observed in this study was the quality of gelatine which include yield, viscosity and tensile strength. The quality of gelatine made from sea bass skin can be seen in Table 1 .

Table 1. Quality of gelatine made from sea bass skin

\begin{tabular}{lc}
\hline Parameter & Value \\
\hline Yield (\%) & $20.036 \pm 0.037$ \\
Viscosity (cP) & $3.40 \pm 0.043$ \\
Gel strength (g bloom) & $138.980 \pm 15.973$ \\
\hline
\end{tabular}

The yield resulted from the treatment was considered affected by a treatment applied on the sample such as the washing, neutralisation of gelatine extract and incomplete hydrolysis process. In addition, the temperature of extraction can also affect the yield. Generally, the yield of gelatine made from fish skin is relatively low in the range of 6-19\% (Kusumaningrum et al., 2018) which was due to the loss of collagen during the washing process, incomplete hydrolysis process and also the collagen dissolving during acid or alkali soaking treatments.

The average viscosity of gelatine made from sea bass skin treated by acetic acid fall into the standard range as 
the viscosity standard for food gelatine is $2.5-4.5 \mathrm{cP}$ (Suptijah et al., 2013). Acetic acid treatment disrupted the non-covalent bonding in the protein (indicated by the swelling of fish skin), exposing the collagen into the environment which increases the solubility and easier for it to be extracted. Subsequently, the acidic treatment also broke down the intermolecular crosslink in triple helix fibres collagen structure, resulting in single chains of amino acids $(\alpha, \beta$ and $\gamma)$ which have higher molecular weight compared to the collagen structure (See et al., 2015). The viscosity of gelatine is related to the average molecular weight of the amino acid chains. Hence, a higher concentration of acid will encourage the hydrolysis of the links yielding more gelatine and resulted in highly viscous gelatine (See et al., 2015; Yudhistira et al., 2019).

The average seabass fish skin tensile strength with a soaking time of $12 \mathrm{hrs}$ was $138.980 \mathrm{~g}$ bloom. This value complies with the gelatine standard of the Gelatine Manufacturers Institute of America, which stated the gel strength of commercial gelatine is in the range of 50-300 g bloom (ASTM, 1993). The longer time of soaking results in excessive hydrolysis of protein collagen and gelatine, therefore, producing oligopeptide (Trilaksani et al., 2012). In addition, some of the amino acids remain and do not run out during the washing process, thus lowering the gel strength.

\subsection{Characteristics of edible film}

\subsubsection{Thickness}

The thickness of edible film with palmitic acid addition is depicted in Figure 2. The smallest thickness in this study was found on $0 \%$ palmitic acid treatment $(0.107 \mathrm{~mm})$, while the highest thickness was found on $4.5 \%$ palmitic acid treatment $(0.321 \mathrm{~mm})$. Increasing the thickness of the edible film as the concentration of palmitic acid increases was due to the increasing amount of soluble solute present in the film. Moreover, the combination of glycerol and palmitic acid can form a good homogenous mixture, which would consequently increase the thickness (Sanyang et al., 2016).

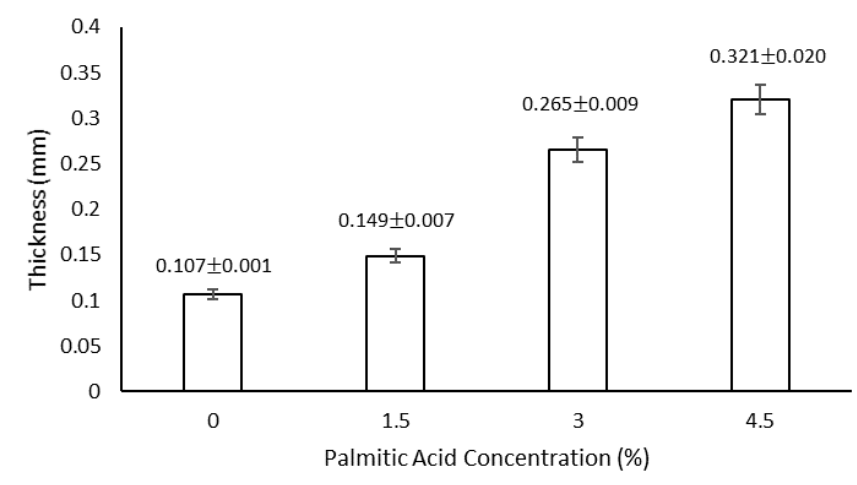

Figure 2. Thickness of edible film from seabass fish skin gelatine with different palmitic acid concentration
The thickness of control edible film and edible film from seabass fish skin gelatine with soybean protein isolate $(0 \%, 3 \%, 4 \%$, and $5 \%)$ addition and $0.7 \%$ glycerol as plasticizer gave thickness of $0.132-0.264$ $\mathrm{mm}$. The highest thickness was found in edible film with glycerol and soybean protein isolate $5 \%$ addition while the lowest was the edible film without the addition of soybean protein isolate. Figure 3 depicts the thickness of edible film from sea bass fish skin and soybean protein isolate addition.

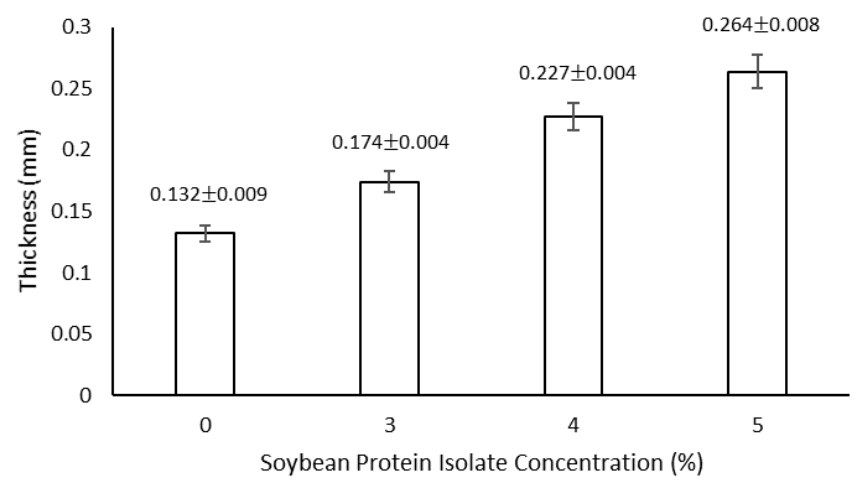

Figure 3. Thickness of edible film from sea bass fish skin gelatine with different soybean protein isolate concentration

The thickness of the edible film increases with increasing soybean protein isolate addition (SPI). This finding was corroborated with the study carried out by Nandane and Jain (2018) which showed that increasing SPI concentration with constant plasticizer concentration gave increasing edible film thickness ranging from 143.162-163.529 $\mu \mathrm{m}$. Increasing the SPI concentration would provide more protein (solute) in the mixture which increases the chance of interactions between the molecules to yield film-building polymer matrices (Salimah et al., 2016; Wulandari et al., 2018). Conversely, lower SPI concentration can reduce the distance of intermolecular chain polymer bounds which reduces the elasticity and water bonding capacity, resulting in the decrease of thickness (Sudaryati et al., 2010).

\subsubsection{Tensile strength}

The tensile strength of edible film with palmitic acid addition is presented on Figure 4, with values ranging from 3.52-10.91 MPa. The highest tensile strength value was found on edible film without the addition of palmitic acid (10.910 MPa), while the lowest was found on the highest palmitic acid addition (3.520 MPa). Tensile strength in edible films is one of the important properties in packaging and coating of products, as it affects the flexibility of the film; high tensile strength would give lower flexibility and low tensile strength would give higher flexibility (Krishna et al., 2012). Edible film with high tensile strength would be more suitable for products requiring stiffer packaging, while edible film with lower 
tensile strength would be more suitable for products requiring flexibility in its packaging (Katili et al., 2013). With that said, the strength of the packaging should be specific and/or complement the properties of the food product.

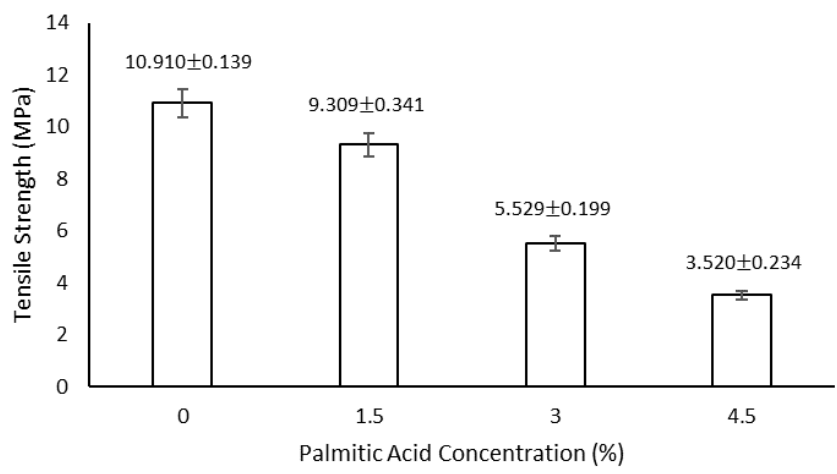

Figure 4. Tensile strength of edible film from seabass fish skin gelatine with different palmitic acid concentration

Tensile strength results of control edible film and edible film made from seabass fish skin gelatine with the addition of SPI $(0 \%, 3 \%, 4 \%$ and $5 \%)$ and $0.7 \%$ glycerol was in the range of 5.130-2.502 $\mathrm{MPa}$ as shown in Figure 5. The highest tensile strength was found in an edible film without the addition of SPI (5.130 MPa) while the lowest strength was found in edible film with $5 \%$ SPI addition (2.502 MPa).

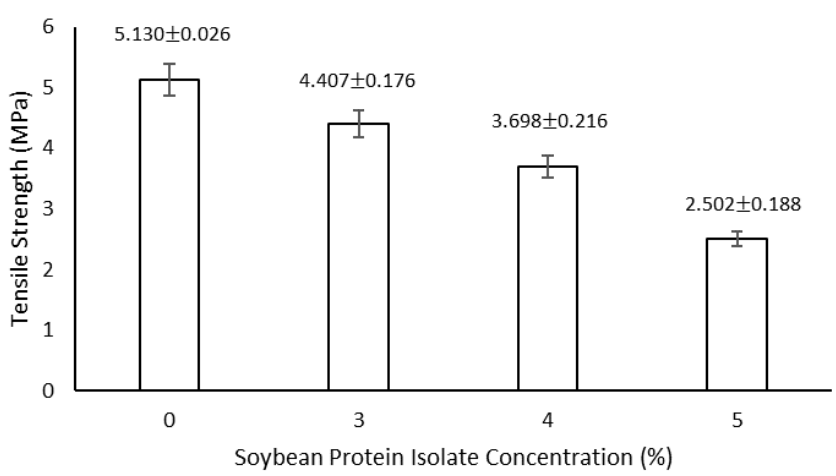

Figure 5. Tensile strength of edible film from seabass fish skin gelatine with different concentration soybean protein isolate

Based on the tensile strength test results of the edible film, it can be inferred that the values tend to decrease. This decrease is suspected due to the increase of palmitic acid and SPI concentration added to the edible film. The constant addition of glycerol plasticizer compared to the increasing concentration of palmitic acid and SPI also played a role, leading to less protein/fat-glycerol attraction, hence promoting the formation of weaker hydrogen bonds between the protein-protein and fat-fat molecules (Sanyang et al., 2015). Subsequently, the domination of strong hydrogen bonds produced by protein-protein and fat-fat intermolecular interaction over the protein-glycerol or fat-glycerol attraction will reduce the tensile strength of the edible film (Bai et al.,
2012)

From the graph, it could also be concluded that edible film with palmitic acid addition has higher tensile strength compared to the edible film with SPI addition. Incorporation of lipids (palmitic acid) into the edible film led to a more compact structure of the film polymer network due to the strong interaction of crosslinking effect between the polymer and lipid particles, decreasing the free volume and mobility of the polymer molecules hence resulting in a higher tensile strength (Galus and Kadzinska, 2016).

\subsubsection{Percent elongation}

Per cent elongation of the edible film with palmitic acid addition is depicted in Figure 6, with results in the range of $21.30-34.44 \%$. The highest elongation value was found on edible film with the highest palmitic acid addition (34.44\%), while the lowest elongation value was found on edible film without the addition of palmitic acid $(21.30 \%)$. The elongation values increase with increasing palmitic acid concentration due to the decreasing of the intermolecular bonds between the polymer chains and the formation of weaker hydrogen bonds which led to increasing elasticity (Sanyang et al., 2015).

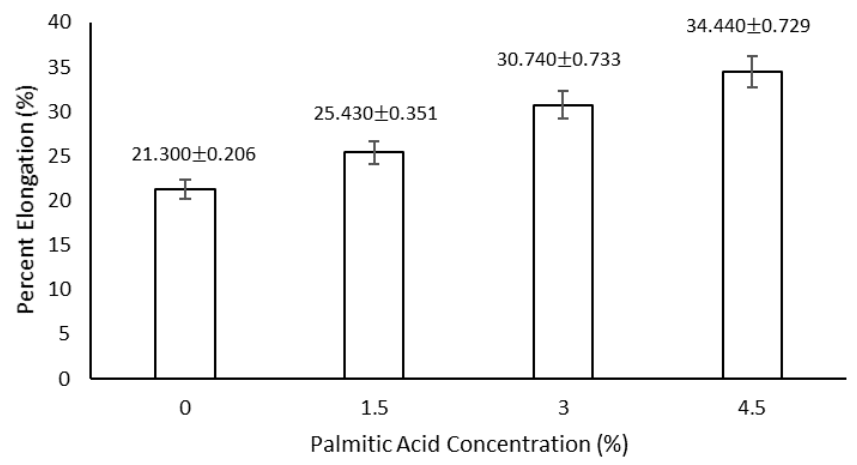

Figure 6. Percent elongation of edible film from sea bass fish skin gelatine with different palmitic acid concentration

Figure 7 shows the per cent elongation of the edible film with the addition of SPI results in the range of $36.063-117.51 \%$. The highest elongation was found in the edible film without SPI addition (117.51\%), while the edible film with the highest SPI addition has the lowest elongation of $36.063 \%$.

Generally, the edible film with palmitic acid addition has lower elongation values compared to the films with SPI addition. Tensile strength and elongation value are inversely proportional since high tensile strength gave more structured and ordered molecules which led to lower flexibility. This statement was also supported by Chakravartula et al. (2019), who stated that edible films with high tensile strength would give lower values of 
elongation at the break due to compatibility and chemical synergetic interaction between components. The significant contrast of values between the tensile strength and elongation results for both edible films with palmitic acid and SPI addition was also due to the same reasons above, where films having little tensile strength is easier to deform and meant requiring higher strain to be broken down (Galus and Lenart, 2013).

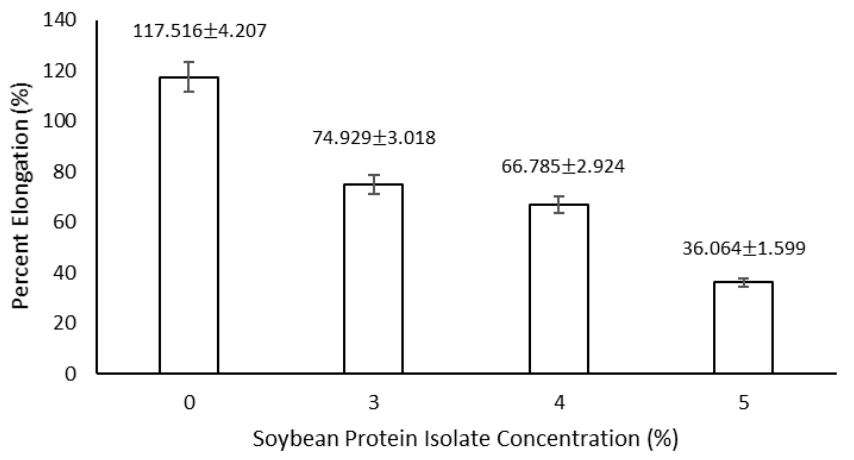

Figure 7. Percent elongation of edible film from sea bass fish skin gelatine with different concentration soybean protein isolate

\subsubsection{Water vapour transmission rate}

The water vapour transmission rate in this study decreases with the increasing addition of palmitic acid as indicated in Figure 8. The lowest value was found on film with $4.5 \%$ palmitic acid concentration, while the highest value was on $0 \%$ palmitic acid concentration. From these results, it can be inferred that the addition of palmitic acid can decrease the water vapour transmission rate. Palmitic acid has a hydrophobic property that will inhibit the rate of water vapour transmission on edible film. Increasing palmitic acid concentration added will result in a film with a low water vapour transmission rate (Seyedi et al., 2015). The fatty acid has a hydrophobic characteristic, consequently, it will inhibit the water vapour transmission rate. Therefore, increasing the concentration of palmitic acid added will result in a smaller rate of water vapour transmission.

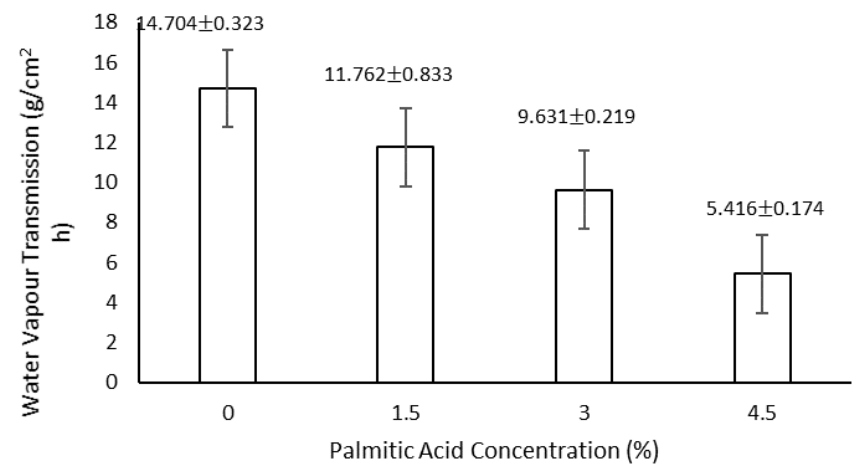

Figure 8. Water vapour transmission rate of edible film from seabass fish skin gelatine with different concentration of palmitic acid

In this study, it could be seen from Figure 9 that the addition of SPI in the edible film gave the average water vapour transmission of $8.910-15.473 \mathrm{~g} / \mathrm{m}^{2} \mathrm{~h}$. The edible film which was made without the addition of SPI has the highest water vapour transmission of $15.473 \mathrm{~g} / \mathrm{m}^{2} \mathrm{~h}$, whereas film with the addition of $5 \%$ SPI has the lowest value $8.910 \mathrm{~g} / \mathrm{m}^{2} \mathrm{~h}$. Low water vapour transmission value indicates edible film could protect food material against water vapour, consequently, the product could have a longer shelf life. The water vapour transmission rate on the Japanese Industrial Standard has a maximum value of $10 \mathrm{~g} / \mathrm{m}^{2} \mathrm{~h}$ (Shinta et al., 2016). Therefore, it could be concluded that from the study results of edible film production with the addition of $3 \%, 4 \%$ and $5 \%$ SPI had met the requirements, while film without SPI addition has not yet met the requirements because the water vapour transmission value was below the given standard.

Water vapour transmission rate results in this study are not only influenced by the concentration of palmitic acid but also by edible film raw material and film thickness. Increasing film thickness will give a lower water vapour transmission rate. The edible film made from gelatine tends to has a high water vapour transmission rate because of its hydrophilic nature. Water vapour transmission rate depends on the ratio of hydrophilic and hydrophobic material in the biofilm formula (Herliany et al., 2013). Generally, biofilm made from protein and polysaccharides has a high water vapour transmission value. Protein is a polar polymer with a big number of hydrogen bonds, therefore resulting in water adsorption in high humidity.

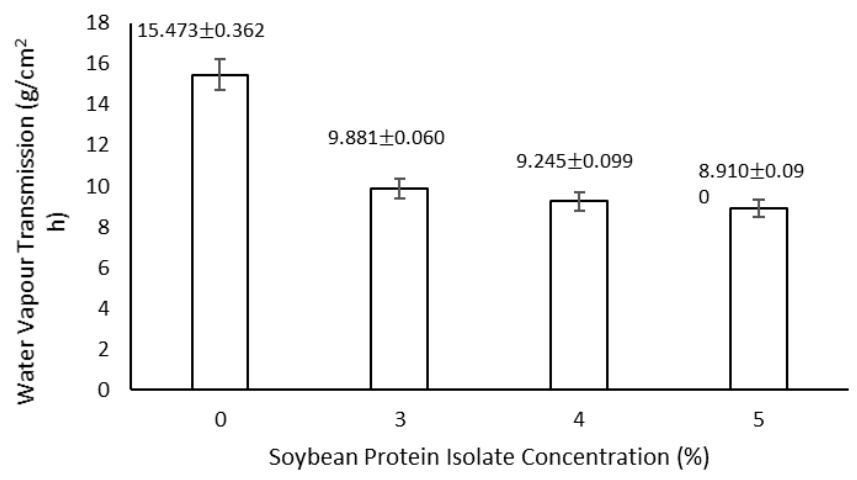

Figure 9. Water vapour transmission rate of edible film from sea bass fish skin gelatine with different soybean protein isolate concentration

\subsubsection{Solubility}

Figure 10 shows the average value of edible film solubility with palmitic acid addition tested on this study is $54.666-92.306 \%$, with the lowest value on the addition of $4.5 \%$ palmitic acid $(92.306 \%)$ and the highest on without addition of palmitic acid $(54.666 \%)$. These results were in accordance with research carried out by 
Julianto et al. (2011), which stated palmitic acid is soluble in organic polar and non-polar solvents. The solubility of fatty acid in water is influenced by the length of the $\mathrm{C}$ chain. The longer the $\mathrm{C}$ chain, the fatty acid will be more difficult to dissolve in water, hence the lower solubility value (Khuwijitjaru et al., 2002).

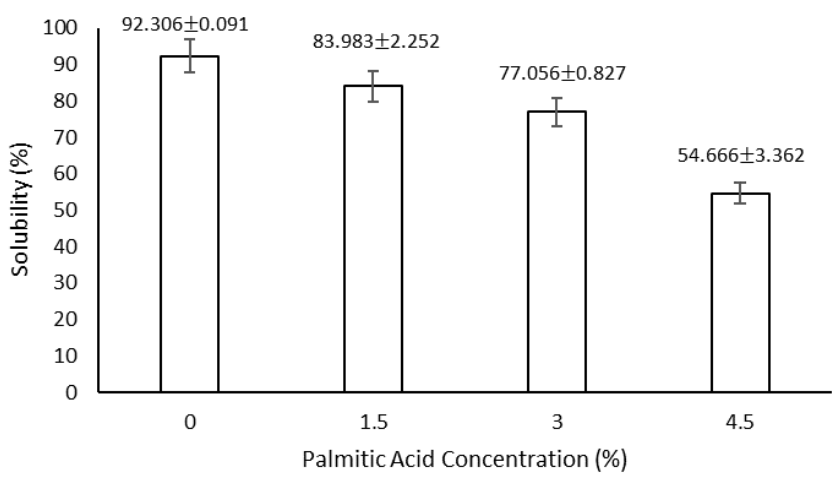

Figure 10. Solubility of edible film from seabass fish skin gelatine with different palmitic acid concentration

The solubility of the edible film with SPI addition showed a decreasing trend (Figure 11), with the highest solubility $(31.670 \%)$ without the addition of SPI and the lowest solubility $(22.800 \%)$ with $5 \%$ SPI addition. SPI addition will produce cross-linking covalent bonds during the edible film formation and as SPI concentration increases, the crosslinking degree will also increase which induced the formation of polymers with high molecular weight. Polymers with high molecular weight are difficult to be dissolved in water, due to the strong inhibition of the interaction between the polymer chains and water by the highly crosslinked polymers, hence the decreasing solubility of the edible film as the SPI concentration increases (Wittaya, 2012; University of Southern Mississippi, 2020).

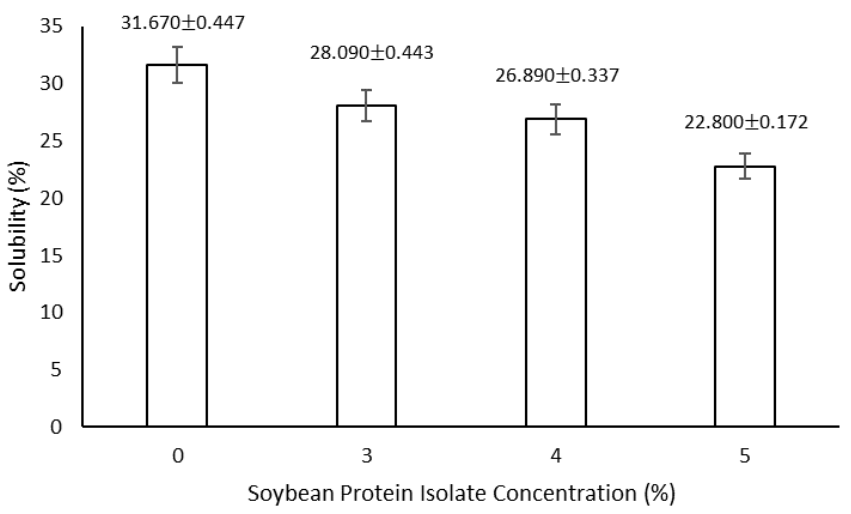

Figure 11. Solubility of edible film from seabass fish skin gelatine with different soybean protein isolate concentration

Solubility will influence the application of the edible film. The edible film with high solubility means it has low protection against water, therefore could only be used in products with low water content. Whereas edible film low solubility could be used in food with high water content because of its difficulty in dissolving. For the purpose of edible food wrapper, a high solubility property in the edible film is needed (Diova et al., 2013).

\section{Conclusion}

The quality of gelatine made from sea bass fish skin through hydrolysis with acetic acid in this study has successfully created and met the regulated gelatine standards, with its viscosity of $3.40 \mathrm{cP}$ and gel strength of $138.980 \mathrm{~g}$ bloom. The addition of palmitic acid (PA) and soybean protein isolate (SPI) on edible film from seabass fish skin gelatine has a significant influence on the characteristics of edible film. Based on the results, edible films with SPI addition yield the best film thickness $(<2.5 \mathrm{~mm})$ while PA addition resulted in better tensile strength of the films $(>3.92 \mathrm{MPa})$ as per the Japanese Industrial Standard due to the strong crosslinking effect between the polymer and lipid particles. Meanwhile, the per cent elongation of both films with PA (21.3-34.44\%) and SPI (36.06-117.53\%) addition decreased with increasing concentration, but SPI generally gave higher elongation compared to PA due to the lower tensile strength found in SPI films which are easier to deform.

Water vapour transmission is one of the key parameters in edible film. It was found that the addition of SPI gave higher water vapour transmission values compared to PA due to the hydrophilic nature of the protein. The addition of $4.5 \%$ PA gave the lowest water vapour transmission $\left(5.416 \mathrm{~g} / \mathrm{m}^{2} \mathrm{~h}\right)$ among all the films because of the hydrophobic nature of lipids which improved the water barrier and resistance in the film. Based on the solubility results, edible films with PA addition (92.306-54.666\%) are easier to dissolve in water compared to SPI films (31.670-22.800\%). Therefore, it was concluded that the best film is the 4\% SPI addition based on its thickness, elongation value, water vapour transmission and solubility results which all met the standard regulations and gave the best values for each property. Subsequently, the use of this edible film is suitable for food products that contain high water content and requiring packaging and/or coating with high flexibility.

\section{Conflict of interest}

The authors declare no conflict of interest.

\section{Acknowledgments}

This research was supported and funded by the Ministry of Research, Technology and Higher Education of the Republic of Indonesia Penelitian Dasar Unggulan Perguruan Tinggi (Grant no. SPK). 


\section{References}

Abdelhedi, O., Jridi, M., Nasri, R., Mora, L., Toldrá, F. and Nasri, M. (2019). Rheological and Structural Properties of Hemiramphus far Skin Gelatin: Potential Use as an Active Fish Coating Agent. Food Hydrocolloids, 87, 331-341. https://doi.org/10.1016/ j.foodhyd.2018.08.005

Alves, M.M., Gonçalves, M.P. and Rocha, C.M.R. (2017). Effect of Ferulic Acid on The Performance of Soy Protein Isolate-based Edible Coatings Applied to Fresh-cut Apples. LWT, 80, 409-415. https://doi.org/10.1016/j.lwt.2017.03.013

AOAC. (2005). Official Methods of Analysis of The Association of Official Analytical Chemists. Washington D.C., USA: Association of Official Analytical Chemist.

Arumugam, G.K.S., Sharma, D., Balakrishnan, R.M. and Ettiyappan, J.B.P. (2018). Extraction, Optimization and Characterization of Collagen from Sole Fish Skin. Sustainable Chemistry and Pharmacy, 9, 1926. https://doi.org/10.1016/j.scp.2018.04.003

ASTM (American Society for Testing and Materials). (1993). Annual Book of ASTM Standards. Philadelphia: ASTM.

Bai, H., Xu, J., Liao, P. and Liu, X. (2012). Mechanical and Water Barrier Properties of Soy Protein Isolate Film Incorporated with Gelatin. Journal of Plastic Film and Sheeting, 29(2), 174-188. https:// doi.org/10.1177/8756087912468744

Bourtoom, T. (2008). Edible Films and Coatings: Characteristics and Properties. International Food Research Journal, 15(3), 237-248.

British Standard 757. (1975). Sampling and Testing of Gelatin, Thickening and Gelling Agents for Food. New York, USA: Academic Press.

Caruso, G. (2016). Fishery Wastes and By-products: A Resource to Be Valorised. Journal of FisheriesSciences.com, 10(1), 12-15.

Chakravartula, S.S.N., Soccio, M., Lotti, N., Balestra, F., Rosa, M.D. and Siracusa, V. (2019). Characterization of Composite Edible Films Based on Pectin/Alginate/Whey Protein Concentrate. Materials, 12(15), 2454. https://doi.org/10.3390/ ma12152454

Diova, D.A., Darmanto, Y.S. and Rianingsih, L. (2013). Karakteristik Edible Film Komposit Semirefined Karaginan dari Rumput Laut Eucheuma cottonii dan Beeswax. Jurnal Pengolahan dan Bioteknologi Hasil Perikanan, 2(4), 1-10. [In Bahasa Indonesia].

Fakhouri, F.M., Martelli, S.M., Caon, T., Velasco, J.I., Buontempo, R.C., Bilck, A.P. and Mei, L.H.I. (2018). The Effect of Fatty Acids on the
Physicochemical Properties of Edible Films Composed of Gelatin and Gluten Proteins. LWT, 87, 293-300. https://doi.org/10.1016/j.lwt.2017.08.056

Galus, S. (2018). Functional Properties of Soy Protein Isolate Edible Films as Affected by Rapeseed Oil Concentration. Food Hydrocolloids, 85, 233-241. https://doi.org/10.1016/j.foodhyd.2018.07.026

Galus, S. and Kadzinska, J. (2016). Moisture Sensitivity, Optical, Mechanical and Structural Properties of Whey Protein-Based Edible Films Incorporated with Rapeseed Oil. Food Technology and Biotechnology, 54(1), 78-89. https://doi.org/10.17113/ ftb.54.01.16.3889

Galus, S. and Lenart, A. (2013). Development and Characterization of Composite Edible Films Based on Sodium Alginate and Pectin. Journal of Food Engineering, 115(4), 459-465. https:// doi.org/10.1016/j.jfoodeng.2012.03.006

Govindharaj, M., Roopavath, U.K. and Rath, S.N. (2019). Valorization of Discarded Marine Eel Fish Skin for Collagen Extraction as a 3D Printable Blue Biomaterial for Tissue Engineering. Journal of Cleaner Production, 230, 412-419. https:// doi.org/10.1016/j.jclepro.2019.05.082

Herliany, N.E., Santoso, J. and Salamah, E. (2013). Karakteristik Biofilm Berbahan Dasar Karaginan. Jurnal Akuatika, 4(1), 10-20.

Hosseini, S.F. and Gómez-Guillén, M.C. (2018). A State -of-The-Art Review on The Elaboration of Fish Gelatin as Bioactive Packaging: Special Emphasis on Nanotechnology-Based Approaches. Trends in Food Science and Technology, 79, 125-135. https:// doi.org/10.1016/j.tifs.2018.07.022

Huang, T., Tu, Z., Shangguan, X., Sha, X., Wang, H., Zhang, L. and Bansal, N. (2019). Fish Gelatin Modifications: A Comprehensive Review. Trends in Food Science and Technology, 86, 260-269. https:// doi.org/10.1016/j.tifs.2019.02.048

Joseph, T.C., Remya, S., Renuka, V. and Jha, A.K. (2019). Fishery Industry Waste: A Resource to Be Valorised. In Joseph, T.C., Jha, A.K., Renuka, V. and Remya, S. (eds). FishTech-19: Fishery Waste Management: Challenges and Business Opportunities in Gujarat, p. 14-24. Gujarat, India: Veraval Research Centre of ICAR-CIFT.

Julianto, G.E., Ustadi, U. and Husni, A. (2011). Karakterisasi Edible Film dari Gelatin Kulit Nila Merah dengan Penambahan Plasticizer Sorbitol dan Asam Palmitat. Journal of Fisheries Sciences, 13(1), 27-34. [In Bahasa Indonesia].

Katili, S., Harsunu, B.T. and Irawan, S. (2013). Pengaruh Konsentrasi Plasticizer Gliserol dan Komposisi 
Khitosan dalam Zat Pelarut Terhadap Sifat Fisik Edible Film dari Khitosan. Jurnal Teknologi, 6(1), 29-38. [In Bahasa Indonesia].

Khuwijitjaru, P., Adachi, S. and Matsuno, R. (2002). Solubility of Saturated Fatty Acids in Water at Elevated Temperatures. Bioscience, Biotechnology and Biochemistry, 66(8), 1723-1726. https:// doi.org/10.1271/bbb.66.1723

Krishna, M., Nindo, C.I. and Min, S.C. (2012). Development of Fish Gelatin Edible Films Using Extrusion and Compression Molding. Journal of Food Engineering, 108(2), 337-344. https:// doi.org/10.1016/j.jfoodeng.2011.08.002

Kusumaningrum, I., Pranoto, Y. and Hadiwiyoto, S. (2018). Extraction Optimization and Characterization of Gelatine from Fish Dry Skin of Spanish Mackerel (Scomberromorus commersoni). IOP Conf. Series: Earth and Environmental Sciences, 144(1), $012036 . \quad \mathrm{https}: / /$ doi.org/10.1088/1755-1315/144/1/012036

Lv, L., Huang, Q., Ding, W., Xiao, X., Zhang, H. and Xiong, L. (2019). Fish Gelatin: The Novel Potential Applications. Journal of Functional Foods, 63, 103581. https://doi.org/10.1016/j.jff.2019.103581

Muttharasi, C., Muralisankar, T., Uthayakumar, V., Gayathri, V., Thangal, S.H. and Anandhan, K. (2019). Utilization of Marine Fisheries Wastes for The Production of The Freshwater Fish Cyprinus carpio. Tropical Animal Health and Production, 51, 2305-2313. https://doi.org/10.1007/s11250-01901938-7

Nandane, A.S. and Jain, R.K. (2018). Optimization of Formulation and Process Parameters for Soy ProteinBased Edible Film Using Response Surface Methodology. Journal of Packaging Technology and Research, 2(1), 203-210. https://doi.org/10.1007/ s41783-018-0045-2

Nilsuwan, K., Guerrero, P., de la Caba, K., Benjakul, S. and Prodpran, T. (2019). Properties of Fish Gelatin Films Containing Epigallocatechin gallate Fabricated by Thermo-compression Molding. Food Hydrocolloids, 97, 105236. https://doi.org/10.1016/ j.foodhyd.2019.105236

Pangesti, A.D., Rahim, A. and Hutomo, G.S. (2014). Karakteristik Fisik, Mekanik dan Sensoris Edible Film dari Pati Talas pada Berbagai Konsentrasi Asam Palmitat. Jurnal Agrotekbis, 2(6), 604-610.

Radziemska, M., Vaverkóva, M.D., Adamcová, D., Brtnický, M. and Mazur, Z. (2019). Valorization of Fish Waste Compost as A Fertilizer for Agricultural Use. Waste and Biomass Valorization, 10, 25372545. https://doi.org/10.1007/s12649-018-0288-8
Salimah, T., Ma'ruf, W.F. and Romadhon. (2016). Pengaruh Transglutaminase Terhadap Mutu Edible Film Gelatin Kulit Ikan Kakap Putih (Lates calcalifer). Jurnal Pengolahan dan Bioteknologi Hasil Perikanan, 5(1), 49-55. [In Bahasa Indonesia].

Sanyang, M.L., Sapuan, S.M., Jawaid, M., Ishak, M.R. and Sahari, J. (2016). Effect of Plasticizer Type and Concentration on Physical Properties of Biodegradable Films Based on Sugar Palm (Arenga pinnata) Starch for Food Packaging. Journal of Food Science and Technology, 53(1), 326-336. https:// doi.org/10.1007/s13197-015-2009-7

Sanyang, M.L., Sapuan, S.M., Jawaid, M., Ishak, M.R. and Sahari, J. (2015). Effect of Plasticizer Type and Concentration on Tensile, Thermal and Barrier Properties of Biodegradable Films Based on Sugar Palm (Arenga pinnata) Starch. Polymers, 7(6), 11061124. https://doi.org/10.3390/polym7061106

See, S.F., Ghassem, M., Mamot, S. and Babji, A.S. (2015). Effect of Different Pretreatments on Functional Properties of African Catfish (Clarias gariepinus) Skin Gelatin. Journal of Food Science and Technology, 52(2), 753-762. https:// doi.org/10.1007/s13197-013-1043-6

Seyedi, S., Koocheki, A., Mohebbi, M. and Zahedi, Y. (2015). Improving the Physical and Moisture Barrier Properties of Lepidium perfoliatum Seed Gum Biodegradable Film with Stearic and Palmitic Acids. International Journal of Biological Macromolecules, 77, 151-158. https://doi.org/10.1016/ j.ijbiomac.2015.03.005

Shinta, D., Supriadi, A. and Lestari, S.D. (2016). Pemanfaatan Air Cucian Surimi Belut Sawah (Monopterus albus) Dalam Pembuatan Edible Film. Jurnal Teknologi Hasil Perikanan, 5(1), 85-93. [In Bahasa Indonesia].

Sudaryati, H.P., Tri Mulyani, S. and Hansyah, E.R. (2010). Sifat Fisik dan Mekanis Edible Film dari Tepung Porang (Amorphopallus oncophyllus) dan Karboksimetil Selulosa. Jurnal Teknologi Pertanian, 11(3), 196-201. [In Bahasa Indonesia].

Suptijah, P., Suseno, S.H. and Anwar, C. (2013). Analisis Kekuatan Gel (Gel Strength) Produk Permen Jelly dari Gelatin Kulit Ikan Cucut dengan Penambahan Karaginan dan Rumput Laut. Jurnal Pengolahan Hasil Perikanan Indonesia, 16(2), 183191. [In Bahasa Indonesia].

Trilaksani, W., Nurilmala, M. and Setiawati, I.H. (2012). Ekstraksi Gelatin Kulit Ikan Kakap Merah (Lutjanus $s p$ ) dengan Proses Perlakuan Asam. Jurnal Pengolahan Hasil Perikanan Indonesia, 15(3), 240251. [In Bahasa Indonesia]. 
Tugiyono, Febryano, I.G., Puja, Y. and Suharso. (2020). Utilization of Fish Waste as Fish Feed Material as An Alternative Effort to Reduce and Use Waste. Pakistan Journal of Biological Sciences, 23(5), 701707. https://doi.org/10.3923/pjbs.2020.701.707

University of Southern Mississippi. (2020). What is Solubility and What it Depends on. Retrieved on December 15, 2020 from https://pslc.ws/macrog/ property/solpol/ps2.htm.

Wibowo, A.H., Listiyawati, O. and Purnawan, C. (2016). The Effects of Plasticizers and Palmitic Acid Toward the Properties of The Carrageenan Film. IOP Conference Series: Materials Science and Engineering, 107, $012043 . \quad \mathrm{https} / / /$ doi.org/10.1088/1757-899X/107/1/012043

Wittaya, T. (2012). Protein-based Edible Films: Characteristics and Improvement of Properties. In Eissa (Ed.). Structure and Function of Food Engineering, p. 43-70. IntechOpen E-Book. https:// doi.org/10.5772/48167

Wulandari, Y., Harini, N. and Warkoyo. (2018). Characterization of Edible Film from Starch of Taro (Colocasia esculenta L.) with Addition of Chitosan on Dodol Substituted Seaweed (Eucheuma cottonii L.). Food Technology and Halal Science Journal, 1 (1), 22-32. https://doi.org/10.22219/fths.vli1.7544

Yudhistira, B., Palupi, E. and Atmaka, W. (2019). The Effect of Acid Concentration and Duration of Submersion Toward the Characteristics of Gelatin of Eel Fish Bone (Anguilla bicolor) Produced Through Acid Process. IOP Conference Series: Earth and Environmental Science, 246, 012046. https:// doi.org/10.1088/1755-1315/246/1/012046 